\title{
CIVIL PROCEDURE: ABSENTEE CLASS MEMBERS SUBJECTED TO DISCOVERY AND CLAIMS DISMISSED FOR FAILURE TO RESPOND
}

In Brennan v. Midwestern United Life Insurance Co., ${ }^{1}$ the Seventh Circuit Court of Appeals held, Judge Stevens dissenting, that identifiable but absent members of a class who received notice of the pendency of the class action, and who failed to respond thereto, may be subjected to the discovery procedures of the federal rules even to the extent of having their claims dismissed with prejudice when they fail to comply with the discovery orders of the court. ${ }^{2}$ A class action had originally been brought for damages allegedly suffered by some Midwestern United Life Insurance Co. stockholders as a result of certain fraudulent securities dealings which had been aided and abetted by Midwestern. ${ }^{3}$ On October 12, 1966, the district court had sent notice to all known and prospective members of the stockholder class, including appellants, informing them of the nature of the suit and of their option to request exclusion from the class represented by the plaintiff, Mrs. Brennan, or to remain in the class and be represented either by the representative stockholder's counsel or by counsel of their own choice. Thereafter, the district court granted the discovery motions of Midwestern ${ }^{5}$ requiring the stockholders to produce certain documents and records, and to respond to interrogatories. Compliance with these orders was directed by Marcli 1, 1967. On January 4, 1967, the representative stockholder's counsel mailed to all class members copies of both the order to produce documents and the interrogatories, specifically mentioning the March 1 deadline. Counsel then sent a letter, on February 20, 1967, to those

THE FOLLOWING HEREINAFTER CITATIONS WILL BE USED:

2 W. Barron \& A. Holtzoff, Federal Practice and Procedure (Wright ed. 1961) [hereinafter cited as 2 BARRoN \& HOLTZOFF];

3B J. MOORE, Federal Practice (2d ed. 1969) thereinafter cited as 3B MOORE];

C. WRIGHT, THE LAW OF FEDERAL CoURTS (2d ed. 1970) [hereinafter cited as WRIGHT];

Kalven \& Rosenfield, The Contemporary Function of the Class Suit, 8 U. CHI. L. Rev. 684 (1940) [hereinafter cited as Kalven \& Rosenfield].

1. F.2d__-(7th Cir. 1971).

2. F.2d at

3. Brennan v. Midwestern United Life lns. Co., 286 F. Supp. 702 (N.D. Ind. 1968), affd, 417 F.2d 147 (7th Cir. 1969), cert. denied, 397 U.S. 989 (1970).

4. Pursuant to Fed. R. CIv. P. 23(c)(2).

5. Pursuant to FeD. R. CIV. P. 33 \& 34 . 
class members who had not yet responded, including appellants, reminding them of the orders and the deadline. On April 17, 1967, the district court ordered that the claims of any class member not responding to the discovery requests within twenty days would be dismissed with prejudice. Again, on May 4, 1967, the stockholders' counsel wrote to those class members, including appellants, who had not yet complied, warning them of the sanction which would be imposed for continued noncompliance. Finally, on August 17, 1967, the district court granted Midwestern's motion to dismiss with prejudice the claims of all class members who had failed to respond to either the interrogatories or a subsequently entered show-cause order. When the class action ultimately came to a conclusion nearly a year later, judgment was entered in favor of the stockholder class. Appellants then filed a motion to set aside the August 17, 1967 order dismissing their claims with prejudice. The district court denied that motion, ${ }^{6}$ and the Seventh Circuit affirmed.

Prior to adoption of the class action device, compulsory joinder was the only means by which a large group of plaintiffs could successfully bring their claims into the federal courts in suits which were classified as "legal." Mass joinder, however, was an awkward and unwieldy procedure when the potential group of interested persons was large, inasmuch as it necessarily presupposed the prospective plaintiffs advancing on the courts en masse. ${ }^{8}$ This problem was particularly severe when the stake of each member of the group was inadequate to impel him to accept the burdens involved in prosecution of a suit. ${ }^{9}$ As the inadequacy of the mass joinder procedure became apparent, attention was focused on the development of a procedural vehicle which would allow mass suit. ${ }^{10}$ The result was the class action, which made adjudication of such cases possible ${ }^{\text {11 }}$ by allowing representatives of a large group of interested persons to sue or be sued on behalf of the whole group, thus obviating the necessity of joining all members. ${ }^{12}$ The class action was originally provided for in Equity Rule 38, which allowed the use of a class action where there were common interests within the group, too many

6. F.2d at

7. 2 BARRON \& HOLTZOFF § 561; 3B MOORE If 23.02, at 23-72.

8. Kalven \& Rosenfield 687-91.

9. Id.

10. WRIGHT § 72 , at 306 .

11. 2 BARRoN \& Holtzoff $\S 561$, at 254.

12. WRIGHT $\S 72$, at 306 . 
interested persons to be brought before the court at one time, and a representative of the class who would fairly present the case for the entire group. ${ }^{13}$ The principal difference between the Equity Rule 38 class action and the mass joinder rules was the point at which the plaintiffs were organized: after a favorable judgment in the former, and before trial in the latter. ${ }^{4}$ When the Federal Rules of Civil Procedure were adopted in 1938, an attempt was made to encourage the expanded use of class actions ${ }^{15}$ by allowing their use in situations where permissive joinder would be proper, ${ }^{16}$ thereby eliminating the previous rule that class actions were available only in situations which would have required compulsory joinder. ${ }^{17}$ Rule 23 was changed extensively in 1966 . While the same basic requirements of numerosity, impracticability of joinder, and adequacy of representation were retained, ${ }^{18}$ certain provisions were introduced which strengthened the effect of judgments in class actions ${ }^{19}$ and made it a more effective method for obtaining relief for relatively small injuries to large numbers of persons. ${ }^{20}$ Of particular significance for present purposes, the 1966 amendments gave the court broad powers to better administer class actions. ${ }^{21}$ Rule 23(d) provides the courts with wide

13. 3B MOORE I 23.02, at 23-74.

14. Kalven \& Rosenfield 691.

15. The class action was made available for all civil actions, whether formerly denominated legal or equitable. In the past the class action had been available only in equity cases. WRIGHT \& 72, at 306.

16. Permissive joinder would be proper where the claims for relief of an interested person arise out of the same transaction or series of transactions as those sued upon, and involve common questions of law or fact. See Fed. R. CIv. P. 20(a).

17. 3B MOORE If 23.02-1, at 23-77.

18. Id. at 23-121.

19. It has been recognized that the judgment in a class action represents an exception to the general rule that, unless one was a party to an action, or was made a party by service of process, he is not bound by the judgment in the action, although the extent of this exception zemains imprecisely defined. Hansberry v. Lee, 311 U.S. 32 (1940). See Pennoyer v. Neff, 95 U.S. 714 (1877); 2 BARRON \& HoLtzoFF § 561, at 63, \& 572, at 125 (C. Wright \& F. Elliott ed., Supp. 1970).

20. The Advisory Committee Note to Rule 23 states that the availability of class actions is extended by Rule 23(b)(3), as revised in 1966, to include controversies in which there are questions of law or fact common to all members of a group, and additionally, that the use of the class action device would contribute to efficiency in adjudication and uniformity in decisions affecting large numbers of people. Ford, Federal Rule 23: A Device for Aiding the Small Claimant, 10 B.C. 1ND. \& COM. L. Rev. 501, 504-07 (1969); Kaplan, Continuing Work of the Civil Committee: 1966 Amendments to the Federal Rules of Civil Procedure (I), 81 Harv. L. REv. 356, 397-98 (1966).

21. Rule 23(d) provided the court with the power to make appropriate orders to determine the course of proceedings or prescribe measures to promote efficiency in the presentation of the case; to require that notice of the course of the proceedings, the extent of the judgment, 
discretion in assuring the fair and efficient adjudication of class actions. ${ }^{22}$ Specifically included is the power to require responses from members of the class to enable the court to effectively define the scope of, and fairly administer the action. ${ }^{23}$ Rule 23(d)(1) and (d)(5), for example, empowers the court to resist the delay and confusion which tend to occur in any action affecting a large number of persons, ${ }^{24}$ to determine the sequence of the proceedings, to expedite the litigation, and to protect the interests of absent class members. ${ }^{25} \mathrm{On}$ its face, however, the rule places no duty of affirmative action on absent class members.

The extent to which absent class members may be required to take affirmative action prior to judgment on the merits is an issue which has received very little attention. ${ }^{25}$ Although non-present class members have been required to provide the court with information concerning the amounts of their claims and the circumstances under which they arose, ${ }^{27}$ these requirements have not been imposed either through the use of discovery procedures or for the purpose of aiding adverse parties in the preparation of their cases. ${ }^{28}$ Rather, the information so acquired has been used by the court to better evaluate the sufficiency of the representation being provided by the named plaintiffs, to make possible a more precise definition of the size and membership of the class than could be obtained otherwise, to determine whether subclasses should be established, and generally to

and the rights of absentees to enter appearances be given to members of the class; and to impose conditions on the representative or on intervenors or to require necessary amendment to the pleadings. The orders may be combined with an order under Rule 16, which provides for determinations by the court concerning the rules governing the presentation of expert witnesses, the calendar for the trial, and similar matters, and may be altered as may be desirable. FED. R. Civ. P. 23(d).

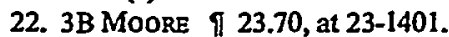

23. Newberg, Orders in the Conduct of Class Actions: A Consideration of Subdivision (d), 10 B.C. IND. \& COM. L. REv. 577, 589 (1969).

24. 3B MOORE If 23.71 , at 23-1411 to -1412.

25. 2 BARRON \& HolTzOFF $\$ 571$ n.79.6; 3B MOORE If 23.75, at 23-1475.

26. F.2d at

27. lowa v. Union Asphalt \& Roadoils, Inc., 281 F. Supp. 391, 403-04 (S.D. Iowa 1968), affd, 408 F.2d 1171 (8th Cir. 1969); Minnesota v. United States Steel Corp., 44 F.R.D. 559, 577 (D. Minn. 1968); Philadelphia Elec. Co. v. Anaconda Am. Brass Co., 43 F.R.D. 452, 459 (E.D. Pa. 1968); Harris v. Jones, 41 F.R.D. 70, 74 (D. Utah 1966).

28. See note 27 supra. In all of these cases, the requests were made at a very early stage in the proceedings, and only basic information, such as the amount claimed and the way in which the claim arose, was obtained. The concern of the court was to find out the membership of the class, and whether there were common questions of law or fact present to warrant the use of the class action device. 
contribute to the fair and efficient adjudication of the case. ${ }^{29}$ These purposes are entirely consistent with those set forth in Rule 23(d) ${ }^{30}$ and are, in fact, essential for the proper maintenance of a class action. By themselves, however, such purposes provide no basis for subjecting absent class members to discovery by an adverse party. Even where absent class members have merely been required to aid the court in the proper administration of the suit, there is no clear indication that sanctions have actually been imposed for failure to respond, although some courts have stated an intention to exclude non-responsive members from the class ${ }^{31}$ or to dismiss their claims with prejudice. ${ }^{32}$ In only one case has a court gone so far as to state that, in addition to the court's requiring that absent class members return completed proof-of-claim forms, it would be allowable for the representatives of the class to request other information from the absentees, as long as no attempt was made to solicit claims.33 The court did not, however, announce any sanction for failure to respond..$^{34}$ Thus, although some requirements have been imposed upon non-present class members, they have been primarily for the benefit of the court, not the antagonists. In no case has the court permitted a party adverse to the class to request information from absent members of the class. In the one case in which the representative of the class was allowed to make requests for information from absentees, sanctions were neither threatened nor imposed for failure of the absentees to comply. Thus, it may fairly be stated that courts have been quite reluctant to require affirmative action from absentee class members..$^{35}$

In Brennan v. Midwestern United Life Insurance Co., the court affirmed the district court's denial of appellants' motion to set aside the dismissal order, relying basically on the cases discussed in the preceding paragraph, and on a comment made concerning them by Professor Moore. ${ }^{36}$ The court held that absent class members who have received notice of the pendency of the suit may be required to

29. See Harris v. Jones, 41 F.R.D. 70, 74-75 (D. Utah 1966).

30. lowa v. Union Asphalt \& Roadoils, Inc., 281 F. Supp. 391, 403-04 (S.D. Iowa 1968); Harris v. Jones, 41 F.R.D. 70, 74-75 (D. Utah 1966); 3B Moore II 23.55, at 23-1161.

31. lowa v. Union Asphalt \& Roadoils, Inc., 281 F. Supp. 391, 403-04 (S.D. Iowa 1968); Minnesota v. United States Steel Corp., 44 F.R.D. 559, $577-78$ (D. Minn. 1968); Philadelphia Elec. Co. v. Anaconda Am. Brass Co., 43 F.R.D. 452, $459-60$ (E.D. Pa. 1968).

32. Harris v. Jones, 41 F.R.D. 70, 74-75 (D. Utah 1966).

33. Minnesota v. United States Steel Corp., 44 F.R.D. 559, 577 (D. Minn. 1968).

34. Id.

35. Korn v. Franchard Corp., 50 F.R.D. 60 (S.D.N.Y. 1970); Berman v. Narragansett Racing Ass'n, 48 F.R.D. 333 (D.R.I. 1969).

36. 3B MOORE If 23.55 , at 23-1161. 
submit to discovery procedures and reveal information which the court finds to be "necessary or helpful" 37 to the fair presentation and adjudication of the suit. The discovery must not, however, be used to harrass the absentees, and they must be fully informed of the discovery orders and the sanctions for failure to comply. ${ }^{38}$ The court stated, in deference to the general policy of Rule 23 giving the absent class member a "free ride" 39 as to the conduct of the case prior to judgment, that absentees should not be subjected to discovery as a routine matter. Nevertheless, the court took the view that requiring some discovery from an absent class member is compatible with Rule 23. Because the absent class member and the representative plaintiff share the same interests with respect to the subject being litigated, and because the rights and liabilities of the absentee and the representative will be adjudicated in the representative suit, the court concluded that the issuance of orders to absent class members invoking the discovery procedures of Rules 33 and 34 is a proper exercise of the powers conferred on the court by Rule 23(d) to make orders in the conduct of class actions. ${ }^{40}$ The criterion which the court offers for determining when the use of discovery is proper, however, is practically indistinguishable from the criteria governing the use of discovery in other kinds of civil actions. Discovery from an absent class member is allowable, according to the court, if it is "necessary or helpful" to the proper presentation and adjudication of the suit.41 No specific reference is made to any of the subdivisions of Rule 23(d)-in which are listed the several purposes toward which orders made pursuant to Rule 23(d) should be directed-in order to indicate which of these purposes the discovery orders in this case were calculated to achieve. In any event, none of the provisions of Rule 23(d) seem to bear a significant relationship to the matter of discovery by the defendant from an absent class member affecting the substance of the case; the purposes for which the court may make "appropriate orders"'42 under Rule 23(d) deal only with maintaining the integrity of the suit as a class action. Also, the court mentions that the record did not reveal any attempt on the part of Midwestern to use discovery procedures to take advantage of class members or as a tactic to

37. —F.2d at —

38. Id. at —

39. Id. at

40. Id.

41. Id.

42. FED. R. Civ. P. 23(d). See note 21 supra. 
discourage claimants. But, again, this does not distinguish the scope of discovery procedures available against a party in an ordinary civil action from the scope of discovery available against an absent member of a class in a class action. Protection is afforded to all persons subject to discovery by the discovery rules themselves. ${ }^{43}$ The dissent argued that the appellants could not properly be considered part of the stockholder class represented by Mrs. Brennan because their interests were somewhat antagonistic to those of the other members of the class by virtue of their unwillingness or inability to respond to the interrogatories. Since the representative may litigate the interests of absentees only to the extent that their interests are genuinely and thoroughly congruous, ${ }^{44}$ the fact that their interests were divergent would have resulted in their exclusion from the class, and placed them outside any judgment rendered in the representative suit. $^{45}$

Brennan is troublesome in several respects. There is literally no case precedent for requiring absent class members to submit to discovery by an adverse party; all but one of the cases relied upon by the court limited the requirement of affirmative action on the part of absentees to providing the court itself with information essential to the proper administration of the suit. ${ }^{46}$ In the remaining case, it was the representative of the class, not an adverse party, who was allowed to request information from the absentees, and the court did not indicate an intention to enforce compliance with those requests through its sanction power. ${ }^{47}$ Further, the Brennan court did not specifically explain how its decision could be reconciled with Rule 23. The court acknowledged the general principle that absentees stand outside the suit prior to judgment, ${ }^{48}$ but failed to show convincingly that any provision of the rule validates the exception to that principle which its holding represents. ${ }^{49}$ In addition to the tenuous support in

43. 2A BARRON \& HOLTZOFF § 715, at 231; WRIGHT § 83, at 369; Newberg, supra note 23 , at 580 .

44. Hansberry v. Lee, 311 U.S. 32,44 (1940).

45. _. F.2d at _ـ

46. These cases are cited at note 27 supra.

47. Minnesota v. United States Steel Corp., 44 F.R.D. 559, 577 (D. Minn. 1968).

48. See note 14 supra and accompanying text.

49. Professor Moore, in stating that the court may impose requirements of affirmative action on absentees, refers to the same cases relied on by the court and discussed at notes 3135 supra. As has been pointed out, in all of these cases the court used its sanction power only upon those requests made to obtain information related to the purposes of Rule 23(d), involving the administration of the suit, and not for discovery by an adverse party which would directly aid in the presentation of his case. 3B MOORE \I 23.55, at 23-1161. 
case precedent and the language of Rule 23 , the proposition that absent class members may be subjected to discovery on a scale approximately the same as parties to other kinds of civil actions diverges sharply from the traditional concept of the class action. Certainly the most distinctive characteristic of the class action is its representative nature. One or more members of the class sue or are sued on behalf of the whole class; by hypothesis, all members of the class are not before the court, and all are not called upon to conduct or defend the suit. This is the duty only of the representative. Although the Brennan court said that discovery procedures, as applied to absentees, are to be closely supervised by the court, the standard adopted for determining when such procedures would be proper is so broad that it can fairly be concluded that discovery procedures may be rather extensively used against absentees. Similarly, while the court stated that absentees should not be subjected to discovery to the same extent as parties to other kinds of civil suits, the standard adopted to govern the use of discovery against absentees is not itself limited by any such qualification. The failure of the court to circumscribe the availabity of discovery against absentees thus creates a potential threat to the integrity of the class action, since it implies that the absentees are at least to some extent to be treated as parties before the court, just as is the representative. Finally, the decision represents a serious departure from one of the policies underlying the Rule 23 class action, namely that of creating a proeedural device which will be genuinely effective in providing recovery to large groups of claimants whose individual stakes in the controversy are too small to support individual suits..$^{50}$ To be effective in this respect, it is essential that the expenditure of time and effort required of each claimant for participation in the recovery be held to a minimum. If the requirements are made too burdensome, this purpose will be frustrated, as potential class members will decide that meeting the requirements for participation in the recovery is not worth the trouble in light of the small size of the individual claims. 1t could well be that the refusal of appellants to respond to the interrogatories in this case was unreasonable; perhaps only a few pieces of easily

50. Eisen v. Carlisle \& Jacquelin, 391 F.2d 555, 560 (2d Cir. 1968); Kaplan, A Prefatory Note, 10 B.C. IND. \& Com. L. Rev. 497 (1969); Starrs, The Consumer Class Action, 49 B.U.L. REv. 211, 407 (1969) (Parts I \& 1I). Cf. Matthies v. Seymour Mfg. Co., 23 F.R.D. 64, 74-75 (D. Conn. 1958). 
obtainable information were requested. ${ }^{51}$ But even a moderate increase in the burden of participating in a class action can be expected to discourage some claimants, and to the extent that this occurs, one important purpose of the class action will be compromised. The Seventh Circuit has possibly served notice on all present and prospective class action defendants that they now have the means to reduce the size of the class through use of the discovery process.

51. To the extent that the need for the information is thought to outweigh the burden on absentee members, this may constitute grounds for excluding such members from the class. See note 44 supra and accompanying text. 
